\title{
Educación médica basada en resultados. II. ¿Fascinación transitoria o nuestro futuro?
}

\author{
A. Wojtczak
}

De acuerdo con lo que expuse en la primera parte del artículo [1], la cuestión que se plantea es si la fascinación por la educación médica basada en los resultados va a perdurar en nosotros, como yo creo, o acabará siendo una experiencia educativa muy interesante, pero una más como tantas otras. Para justificar mi optimismo quisiera referirme nuevamente a los artículos publicados en el número de Medical Teacher dedicado a este tema [2].

La implementación de los requerimientos globales mínimos esenciales (GMER) y los procedimientos puestos en marcha para evaluar los resultados de aprendizaje permiten conocer qué estudiantes y facultades de medicina presentan fortalezas, aquellos que se encuentran en una zona fronteriza y aquellos que necesitan mejorar. Ello ha permitido presentar el libro blanco de la reforma de la educación médica en China [3]. El informe de la Facultad de Medicina de la Universidad de Sun Yat-sen [4], elaborado con el apoyo del Ministerio Chino de Educación, comparte sus experiencias en la implementación de la evaluación de los GMER y concluye que es posible que el esfuerzo llevado a cabo por el IIME en su proyecto de los GMER pueda producir una mejora remarcable en la calidad de la educación y de la atención sanitaria en China y a nivel mundial, tal y como lo hizo en su momento el informe Flexner. En dicho momento, las cinco Facultades de Medicina escocesas [5] se pusieron de acuerdo en un conjunto de resultados de aprendizaje que ha servido de punto de referencia para la educación médica en Escocia y en otros países. En Vietnam [6], más de mil profesores y otros expertos procedentes de ocho Facultades de Medicina trabajaron conjuntamente para desarrollar unos objetivos de aprendizaje detallados y unos resultados esperados, y enfatizaron los conocimientos, actitudes y habilidades que se esperaba que adquiriera un médico graduado en cualquier Facultad de Medicina vietnamita. En México [7], 120 académicos y decanos de las Facultades de Medicina trabajaron conjuntamente para identificar de forma consensuada los resultados del aprendizaje y los requerimientos esenciales mínimos de los graduados en Medicina. Durante la $4 .^{\mathrm{a}}$ Conferencia Asia-Pacífico de Educación Médica celebrada en Singapur en febrero de 2007 [8], cuatro facultades de Escocia, Estados Unidos, Pakistán y Singapur presentaron un estudio de casos de sus currículos basados en resultados de aprendizaje, lo que facilitó una perspectiva internacional sobre el camino a seguir por la reforma de la educación médica.

La Comisión Europea, por su parte, ha apoyado y financiado ampliamente el proyecto Tuning para establecer los resultados de aprendizaje en todas las disciplinas en la Educación Superior Europea. Un panel de expertos estableció y validó los resultados de aprendizaje para Medicina [9] para ser usados por los diferentes países. Además, la Asociación de Estudiantes Europeos de Medicina (EMSA) y la Federación Internacional de Asociaciones de Estudiantes de Medicina (FMSA) elaboraron un cuerpo curricular para los estudiantes de medicina europeos basado en 76 resultados de aprendizaje.

En el campo de la formación especializada, la red basada en competencias denominada CanMEDS [10] promovida por el Royal College of Physicians and Surgeons de Canadá también se está reconociendo ampliamente fuera del país. Se ha extendido recientemente a la educación pregraduada en la Universidad de Ottawa. En Estados Unidos, el Accreditation Council for Gradua-
Ex director del International Institute for Medical Education (IIME).

Ex presidente de la Association for Medical Education in Europe (AMEE)

E-mail 
te Medical (ACGME) está implementando con éxito el proyecto Outcome [11]. Este proyecto está focalizado en la evaluación del rendimiento del residente y entiende que la calidad de la atención sanitaria depende de la adquisición y aplicación por los residentes de sus competencias de forma efectiva.

Lo que se necesita para implementar ampliamente la educación basada en los resultados y transformar los currículos existentes es actuar como los 'castores' [12], es decir, trabajar duro y superar todas las dificultades. Ello requiere una planificación adecuada, un liderazgo apoyado por la experiencia en la educación médica, recursos financieros y perseverancia. Pero la bola de nieve llamada 'educación basada en resultados' está rodando y todos aquellos que duden en empezar a realizar este esfuerzo confiando en que pasará de moda, en mi humilde opinión, serán los perdedores. La educación basada en los resultados ya no es más un experimento, es una realidad mundial. Esto es lo que justifica mi optimismo.

\section{Outcome-Based Medical Education II. Transitional fascination or our future?}

In view of what was said in the Part 1 [1], the question arises, if the $O B E$ actual fascination is going to stay with us for good, what I believe in, or will fade away, as a very interesting educational experiment, as think many others. To justify why I am optimistic, I will once more to refer to the papers published in the theme issue of the Medical Teacher [2].

The implementation of the GMER and the assessment procedure matching the learning outcomes allowed for conclusions as to where a student, a school and all schools had strengths, where they were on borderline in performance or where they need improvement. It permitted to present the blueprint for medical education reform in China [3]. The report from the Medical School of Sun Yat-sen University [4] shares their experiences in implementing the GMER evaluation, concluding that it is possible that the IIME-GMER effort can bring a remarkable improvement in the quality of education and patient care in China and around the globe as the effect of the Flexner report. It can be added that this report has been prepared with the support of the Chinese Ministry of Education. The five medical schools in Scotland [5] agreed on a framework and a set of learning outcomes that are steering the medical education in Scotland and beyond. In other parts of the world in Vietnam [6] more than a thousand teachers and other experts, from eight medical schools, worked together to develop detailed learning objectives and expected outcomes focusing on knowledge, attitudes and skills that are ex pected of a medical doctor graduating from any medical school in Vietnam. In Mexico [7] 120 faculty members and deans of medical schools worked collaboratively to identify, by consensus, national outcomes and minimum essential ments for medical graduates. During 4th Asia Pacific Medical Education Conference in Singapore in February 2007 [8], the four schools from Scotland, USA, Pakistan and Singapore, presented a case studies of their OBE curriculum, providing an international perspective of the direction of medical education reform.

The European Commission supported and funded a sector-wide the Tuning Project to develop learning outcomes for all disciplines in Higher Education in Europe. The learning outcomes for medicine [9] were developed and validated by an expert panel to be used by countries. In addition the European Medical Students' Association (EMSA) and the International Federation of Medical Students' Associations (IFMSA) have produced a core curriculum for European medical students based on 76 learning outcomes.

In the field of the specialty training, the outcomebased framework called the CanMEDS [10] initiated by the Royal College of Physicians and Surgeons of Canada are actually broadly recognized also outside country. It has been extended recently to undergraduate medical education at the University of Ottawa. In the USA, the Accreditation Council for Graduate Medical (ACGME) is successfully implementing the Outcome Project [11]. It focuses on the assessment of resident performance understanding that quality of care depends on acquiring and applying, by residents, possessed competences effectively.

What is needed for a broad implementation of $O B E$ to transform the existing curricula is to behave like "beavers" [12] working hard and overcoming all difficulties. It requires adequate planning, leadership backed up by expertise in medical education, financial resources and persistence. But the snowball called the $O B E$ is rolling and all hesitant to start this effort and hoping that it will fade away, in my humble opinion will be looser. The OBE is not anymore experiment, it is a worldwide reality. This is what justifies my optimism. 


\section{Bibliografía}

1. Wojtczak A. Educación médica basada en resultados. I. Principios básicos y ventajas. Educ Med 2008; 11: 43-4.

2. Harden RM. Outcome-based education: the future is today. Med Teach 2007; 29: 625-9.

3. Schwarz MR, Wojtczak A, Stern D. The outcomes of global minimum essential requirements (GMER) pilot implementation in China. Med Teach 2007; 29: 699-705.

4. Xiao H, Xian L, Yu X, Wang J. Medical curriculum reform in Sun Yat-sen University: implications from the results of GMER evaluation in China. Med Teach 2007; 29: 706-10.

5. Ellaway R, Evans P, Mckillop J, Cameron H, Morrison J, Mckenzie H, et al. Cross-referencing the Scottish doctor and tomorrow's doctors learning outcome frameworks. Med Teach 2007; 29: 630-5.

6. Hoat LN, Yen NB, Wright P. Participatory identification of learning objectives in eight medical schools in Vietnam. Med Teach 2007; 29: 683-90.
7. Elizondo-Montemayor L, Cid-García A, Pérez-Rodríguez, BA, Alarcón-Fuentes G, Pérez-García, I, David S. Outcome-based national profile of Mexico's medical graduates. Med Teach 2007; 29: 691-8.

8. Davis MH, Amin Z, Grande JP, O'Neill A, Pawlina W, Viggiano $\mathrm{T}$, et al. Case studies in outcome-based education. Med Teach 2007; 29: 717-22.

9. Cumming A, Ross M, Steering Group and Task Force of the MEDINE Thematic Network. The Tuning Project for Medicine-learning outcomes for undergraduate medical education in Europe. Med Teach 2007; 29: 636-41.

10. Frank JR, Danoff D. The CanMEDS initiative: implementing an outcomes-based framework of physician competencies. Med Teach 2007; 29: 642-7.

11. Swing SR. The ACGME outcome project: retrospective and prospective. Med Teach 2007; 29: 648-54.

12. Harden RM. Outcome-based education -the ostrich, the peacock and the beaver. Med Teach 2007; 29: 666-71. 